\title{
New Turkish Citizenship? \\ Contestation of Muslim Women \\ and LGBT Organizations
}

\section{Doğu Durgun, Elif Kalaycıoğlu}

In the last two decades, Turkey's citizenship regime has come under increasing challenge from various segments of society. Falling largely in line with the civicrepublican tradition, the gendered, ethnically exclusionary and secular citizenship notion in Turkey traditionally prioritized duties and obligations over rights, and therefore a passive and obedient citizenry (Kadığlu 2005). The »common good « of the republican state was defined through an elite consensus as progress towards contemporary Western civilization. The definition of the ideal citizen as a secular-Sunni, male, heterosexual Turk led to the subordination of women, ethnic and religious minorities, as well as sexually marginalized groups, and pious Muslims. Most of these groups organized themselves into social movements in the 199os and 200os, in connection with the dynamics of globalization and efforts toward European accession. Some introduced their claims of self-preservation and realization within the emancipatory possibility of inclusive citizenship, while others had a more communitarian focus (Keyman and İçduygu 2003).

In this paper, we focus on two groups of challengers to the existing notion of citizenship - the LGBT (Lambdaistanbul, Kaos GL and the Association of Social Policies, Sexual Identity and Sexual Orientation Studies (SPOD) and Muslim Women's Associations (AK-DER and Başkent Women's Platform). While these groups have moments of divergence in their conceptualization of the political, they share important similarities in their invocation of inclusive citizenship, fundamental rights and freedoms, and the nondiscriminatory state. We argue that such claims, which project radical heterogeneity, can be accommodated only by a radical democratic polity (Mouffe 1992, Mouffe 1995, Lister 2003), by which we understand a constant contestation of competing conceptualizations of the common good.

This contestation is to take place within a dialogical framework, which requires the »common recognition of a set of ethico-political values« (Mouffe 1992: 
79). The set of values is an overarching normative framework that does not substantiate a universal concept of common good, but instead comprises mechanisms for discussing the competing concepts. It is the "grammar of conduct, « constituting the loyalty of citizens to one another and to living together, where living together is understood as a good in itself. A radical and plural democracy, argues Mouffe, requires the creation of a chain of equivalences between groups that engage in democratic struggles (Mouffe 1992: 70). This chain of equivalences moves beyond the "false debate " between the liberal conception of a collection of individuals with no common purpose and the republican conception of a single common good (Mouffe 1992: 75). Instead, the citizenry, whose members are »engaged in many different purposive enterprises and with differing conceptions of the good, «share a common recognition of a set of ethico-political values (Mouffe 1992: 79). It is through this shared set of values and a common self-understanding as radical democratic citizens that different groups and struggles can create a chain of equivalences (Mouffe 1992: 79-80).

Within this framework, the common grammar of conduct is underlined by the acceptance of the principle »freedom and equality for all, (Mouffe 1992: 75) and is inclusive of the ethico-political principles of the polity (Ibid 81). At the theoretical level, this necessitates overcoming the binaries of liberal/republican, public/private, and equality/difference that have been at the center of citizenship debates. Thus, we turn first to these binaries. We then analyze the ways in which the Muslim Women's and LGBT associations transcend them. We conclude by arguing that while the transcendence of such binaries is necessary for a radical democratic polity, it might not be enough. Although both groups challenge a substantive common good by their emphasis on liberal rights, the prejudice, which we mention below, still remains. It is yet to be seen whether a joint stand will be established by seeing each other as co-eval actors, struggling for a common democratic polity.

\section{Three Binaries of Citizenship Debates}

The civic-republican and liberal-individualist conceptualizations of citizenship have largely dominated the debate on citizenship. Civic republicanism assumes the moral priority of community to individual, whereas the liberal-individual tradition is founded upon the primacy of the individual (Rousseau 1978; Rawls 1972; Dworkin 1977; Pocock 1995). The former brings to the fore the language of duties and obligations to the community, and the liberal language of citizenship emphasizes individual needs and entitlements. In the republican public sphere, individuals come together and collectively engage with the creation of the political. Activities and practices, such as work, military service and taxes become basic tenets 
of citizenship. The liberal citizenship is rather a legal status based on and guaranteeing rights and freedoms, where a minimal state is the guarantor. Prioritizing the community, the republican tradition fails to acknowledge the liberal contribution on the protection of individual rights. The liberal tradition, on the other hand, fails to offer a noninstrumental, public-spirited answer to the question of coexistence. Yet, the two traditions can be reconciled through a perspective that recognizes the gains of the liberal democratic revolution, while reestablishing the lost connection between ethics and politics through republican notions of publicspiritedness and civic virtue (Mouffe 1992: 75).

In Turkey, the civic-republican tradition has historically dominated. The promotion of the common good created a »militant « citizen to the detriment of individual rights (Keyman and Üstel cited in Kadıŏlu 2005: 9-10). Within this framework, liberal individualism has aided the emancipatory efforts of many groups. The principle of the right to life, and freedom of conscience and belief have been utilized by sexual minorities and Muslim women in their campaigns for an inclusive citizenship. While both groups utilize liberal tenets, the public debate over Islam and homosexuality during 2010 demonstrates that liberal conceptions do not necessarily extend beyond particular interests to create a wider political community. Consequently, the societal vision of prominent Muslim intellectuals, such as Hilal Kaplan, ${ }^{1}$ and some LGBT activists, fell short of the establishment of a common "grammar of conduct. "Such understandings of a wider community could be better provided by republican notions.

The debate on the inclusion of excluded groups has been viewed through the equality vs. difference binary prism. The projection by dominant groups of their particularities as universal results in the construction of certain groups as »different, « and, subsequently, their exclusion from »value-neutral « public space. Republican citizenship leads to this exclusion through the conceptualization of a single public space, where citizens share a substantive idea of the common good and interact as a homogeneous group. Liberalism tries to overcome it by prioritizing equal opportunity towards the removal of barriers to equality (Longo 2001: 270). However, liberalism fails to recognize that the problems of participation in the public sphere are multiple and interconnected (Fraser 1992). For instance, liberalism promotes the participation of women in politics through mechanisms such as quota requirements. Yet, it fails to acknowledge that women often undertake unpaid domestic and care work. A reframing of the equality/difference debate is therefore necessary. In doing so, we should remember that equality does not need to mean sameness, and difference does not mean inequality per se. Instead,

1 For Kaplan, see http://www.taraf.com.tr/haber/islam-ve-escinsellik-meselesi.htm, available on October 28, 2012. 
equality through recognition of differences is possible. Indeed, radical plural democracy points to this possibility. It acknowledges that even though segments of society are perceived as different, they can participate equally without the imposition of sameness. Lister (2003) points to this possibility through distinct understandings of difference, namely strong and weak. The strong version sees as essential differences amongst groups of individuals, whereas the weak version stresses the constructed nature of difference in biological and socio-cultural terms. A nonessential conceptualization of difference recognizes the possibility of change as well as equality through difference.

Lastly, the division of public and private is at the crux of the constitution of the political. Both the liberal and republican traditions of citizenship have their respective constructions of the public and private spheres. For the liberal tradition, the private is the sphere of particularities, difference, and morality. It is protected by the state. The public sphere is nonmoral and political, and devoid of these particularities. The republican tradition sees the public as the embodiment of the common good. The private, on the other hand, comprises important institutions such as family and religion, yet insofar as the public actively creates citizens it imbues the private. Both traditions have been challenged by the feminist scholarship (Pateman 1988; Fraser 1992; Lister 2003). Feminist theories demonstrate how the public-private distinction is based on, and sustains, culturally intelligible norms of femininity and masculinity, and the hierarchies between the two. The construction of the public as masculine and the private as feminine leads to the exclusion of women and sexual minorities from the public sphere. In challenging this dichotomy, the excluded groups advocate that their particularities, which had been relegated to the private sphere, are, in fact, political matters. Arguing that the private/public dichotomy reproduces the hierarchy between groups, some began to form »subaltern counterpublics «(Fraser 1992). Civil society organizations created a forum of discussion where groups sought to expand and pluralize public space. However, counterpublics that are themselves " homogeneous " fall short of the radical democratic approach which imagines, »the creation of a chain of equivalences between different democratic struggles " (Mouffe, 1992: 70). In other words, even if they are not necessarily in coalition, the democratic struggles are expected to operate within an awareness of each other and a common "grammar of conduct."

We have tried to argue that a debate on citizenship that takes place through multiple dualities is inadequate in conceptualizing an inclusive and nonhierarchical polity. In pointing out the limitations, as well as the contributions of these debates, we have suggested a radical democratic polity as a meaningful way of moving beyond the limitations. We believe that a radical democratic polity is fundamentally tied to human agency and autonomy because it recognizes both the importance of fundamental rights in enabling such autonomy, as well as the signi- 
ficance of public participation towards the full realization of human agency. With this theoretical framework in mind, we now turn to our case study.

\section{Transcending the Binaries: Muslim Women's and LGBT Organizations}

The first attempts to organize activities for sexual liberation began with, and were subsequently prohibited by, the governorship of Istanbul in 1993. Soon after, Lambdaistanbul began to organize itself as a solidarity association in Istanbul. In Ankara, Kaos GL began to publish its magazine in September 1994. Kaos GL and Lambdaistanbul opened cultural centers in 1999 and 2002 respectively. Kaos GL and Lambdaistanbul were officially recognized as an association in 2005 and 2010 respectively. Pembe Hayat and Istanbul LGBTT, which focus on transgender individuals' rights, followed suit. Finally, SPOD was established in September 2011. Due to municipality and governorship bans, the first pride weeks and gatherings were organized in LGBT bars and clubs. Still, the organizations enabled the formation of associational life, resulting in established collectivities in the 20oos. The Europeanization process, and the accompanying funds, opened up a space for capacity building. In the late 1990 os and early 200os, a citizenship discourse was introduced, claiming LGBTs' individual, political and social rights. The organizations began to publicly voice these demands through demonstrations, pride parades and by setting up booths to distribute information. The first public appearance of LGBTs was on the May $1^{\text {st }}$ demonstration of 2001 in Ankara. Two years later, the first pride parade was organized in Istanbul with the participation of approximately 50 people. Since then pride parades have been organized annually. The growing contestation of the socio-cultural and political system can be observed throughout 200os, exemplified in the last parade, which gathered a crowd of approximately 5,000 people. Currently, several LGBT organizations operate in multiple provinces.

Başkent Women's Platform was one of the five platforms established in different cities in 1995, as a result of meetings with conservative associations. ${ }^{2}$ Its activities initially focused on combating discrimination faced by Muslim women as a result of both conservative and modern prejudices. With the 28 February 1997 coup, the headscarf ban became another important focus for advocacy. AK-DER was established in the aftermath of the 28 February coup, and it has focused on advocating on behalf of victims of the ban. ${ }^{3}$ Both associations carry out aware-

2 http://www.baskentkadin.org

3 http://www.ak-der.org 
ness-raising and advocacy activities through a variety of tools such as conferences, sit-ins in front of universities, legislation proposals, and publication of reports. Some of the other Muslim women's organizations, such as Şefkat-Der ${ }^{4}$ and ÖzgürDer, ${ }^{5}$ which were established around the same period, have slightly different foci. Şefkat-Der has concentrated on charitable activities, whereas Özgür-Der has pursued more Islam-centric advocacy. However, both the Platform and AK-DER are closely connected to the processes of globalization and Europeanization in their discourse and practice. ${ }^{6}$ While they have chosen not to utilize the European Union to maintain neutrality, they have looked to Europe for collaborations, best practices and anti-discrimination resources concerning women.

\section{Individual Rights for an Inclusive Public}

These groups consider Turkey's republican model of citizenship to be homogenizing and monolithic in its conception. The exclusively secular and heteronormative public involved the repression of headscarf wearing women and LGBTs in the pursuit of western contemporary civilization and "properly « established families as the basic units of the republican society. The groups utilize liberalizing reforms in Turkey that have been influenced by globalization and Europeanization, in order to present their challenges. Freedom of expression, freedom of speech, freedom of association and organization, and freedom of conscience protect and ensure that these groups are able to articulate their claims of belonging and participation.

Several closure cases, filed by governorships in Ankara, Istanbul and Izmir against the LGBT organizations were countered by demands for freedom of association. The closure case of Lambdaistanbul ${ }^{7}$ in 29 May 2008 demonstrates how a singular notion of the common good impedes the public participation of LGBTs. The Governorship referred the Office of Associations to investigate Lambdaistanbul's preamble. The Office declared that the preamble violated the patriarchal structure, the sacred character of the family and religion, and "public morality." Claiming their right to form associations, and invoking the liberal notion of citizenship through individual rights protection, Lambdaistanbul appealed the decision, which was annulled on 5 May 2010. Yet, the final decision in favor of Lambdaistanbul admonished that the organization can be closed if it »encourages, exhorts

\footnotetext{
4 http://www.sefkatder.org

5 http://www.ozgurder.org

6 Soysal diagnoses a similar trend for Muslim associations in Europe in the first half of 1990s. (see Soysal 1997)

7 For details, see http://bianet.org/biamag/bianet/114196-lambdaistanbula-karsi-kapatmadavasi-kronolojisi, available on June 12, 2012.
} 
and diffuses different sexual orientations. «Such vague definitions pose structural legislative and judicial problems for LGBT groups. These groups resist the state elite's definition of the common good through slogans such as » whose morality is the common morality." LGBT organizations argue that LGBTs face problems in accessing public services due to the lack of an explicit recognition of »sexual orientation and sexual identity, « relying on the liberal notion of human rights.

Muslim women's associations invoke freedom of conscience and freedom from discrimination in contesting the republican notion of citizenship. The 28 February 1997 military intervention, which was based on February $28^{\text {th }}$ decisions of the National Security Council, was a turning point in the struggle for inclusion. The decisions set out a general framework for the full implementation of laws for the maintenance of laicism in Turkey. These laws included the law on attire, which punishes the wearing of the headscarf in public places defined as "state spaces. " Its rigorous enforcement resulted in the expulsion of headscarved women from institutions of higher education, and certain professions such as public servants and officials, teachers and lawyers. Başkent Women's Platform has argued that rights and freedoms are not granted by the state, but are a fundamental part of being an individual. For both the Platform and AK-DER, ${ }^{8}$ the choice for women to wear a headscarf should be understood within the framework of fundamental human rights, freedom of belief and conscience. The Platform thereby places the burden of proof on the state, which cannot arbitrarily restrict rights and freedoms. AK-DER argues further that in exercising fundamental rights shared by all citizens, including the right to work, receive education and health services, individuals should be left free in their choice of clothing.

These groups also reveal the limitations of the liberal horizons. For Muslim women, the inadequacy of liberalism begins with the contradiction that whereas liberalism defines rights, such as the headscarf, as private, their exercise might be public. ${ }^{9}$ This contradiction has led Muslim women's associations to conceptualize a democracy that is inclusive in a sense that extends beyond their particularity. AK-DER has put forth a proposal for inclusive education, which recognizes the right of all ethnic and religious groups to give and receive education in their mother tongue and in accordance with their traditions. ${ }^{10}$ The Platform has entered

8 See »Why is the headscarf banned? «: http://www.ak-der.org/basortusu-neden-yasak-2008. gbt. and also »Headscarf: The Problem that cannot be Covered, « http://www.ak-der.org/ kitap.gbt., available on June 12, 2012.

9 Secreteriat General Neslihan Arıbulut Akpınar's »Preface « to »Headscarf: The Problem that cannot be Covered, « http://www.ak-der.org/ortulemeyen-sorun-basortusu---kitap---onsoz. gbt., available on June 10, 2012.

10 http://www.ak-der.org/insan-haklari-ve-ihlaller-ekseninde-bir-ornek-turkiyede-basortusuyasagi-sorunu.gbt, available on June 10, 2012. 
into feminist and anti-militarist alliances. Within these collaborations, it has carried out investigative fieldwork with human and women rights organizations in the case of Uludere airstrikes, in which 34 civilians were mistaken for PKK members and killed in aerial bombings, and has demanded public accountability. ${ }^{11} \mathrm{AK}-$ DER participated, with other civil society organizations, in fieldwork to investigate markings of Alevi houses in Adiyaman. ${ }^{12}$ In the resulting report, AK-DER asked for an in-depth investigation of the incident, and its implications for peaceful coexistence of different religious groups. Such cooperation is present in the case of LGBT organizations, SPOD and Kaos GL, and Lambdaistanbul as well, and involves collaboration with feminists and Kurds (i.e., participation in The Democratic People's Congress), carrying Armenian, Kurdish and Turkish placards in demonstrations, and coalitions with anti-militarist groups in the case of conscientious objectors. These collaborations demonstrate a public spiritedness and desire for a more inclusive citizenry.

\section{Equality in Plurality}

The citizenship discourse and practice of these groups transcended the difference/ equality binary by arguing that equality through difference is possible. Their nonessentialist conceptions of difference have allowed them to recognize their own shifting and plural subject positions. Herein lies the promise of the equivalence of democratic struggles, as well as the possibility of a common "grammar of conduct, « essential for a radical democratic polity.

LGBT organizations demand equal recognition through difference, as witnessed in publicized court cases filed by individuals and organizations. The case of referee Halil İbrahim Dinçdağ is one such example. ${ }^{13}$ Dinçdağ was discriminated against by the Trabzon Board of Referees and Turkish Football Association when he took a report of exemption from military service based on his sexual orientation. The Board of Referees decided on the basis of the private statute of the Association that those who do not fulfill their compulsory military service due to »diseases « cannot be a referee. The lawyer of Lambdaistanbul and Dinçdağ claimed that the decision was extra-legal since homosexuality is not considered as a disease by the Constitution. The claim was made for equal rights to serve as citizens.

11 For collaborations and Uludere investigation see: http://www.baskentkadin.org/tr/?cat=11 and http://www.baskentkadin.org/tr/?page_id=115, available on June 10, 2012.

12 For the report, see http://www.ak-der.org/adiyamanda-alevi-ailelerin-ikamet-ettigi-evlerinisaretlenmesi-ile-ilgili-inceleme-raporu.gbt., available on June 12, 2012.

13 See http://bianet.org/bianet/toplumsal-cinsiyet/135982-gey-hakemin-hukuk-mucadelesi, available on June 12, 2012. 
They pointed out the systemic reasons of unemployment in the LGBT community, and especially the transgender community. In doing so, they focused their critique on the nonrecognition of the equal capabilities that LGBTs have, which do not allow these individuals to work in the jobs they freely choose. The organizations voiced their claims to be treated as individuals with equal capacities through campaigning on individual cases of discrimination in the work place. They insisted that they were different in terms of their sexual orientation, but equal in terms of human agency, autonomy and capacity.

The exemption of GBT individuals from military service further demonstrates how these organizations strategically claim their equality within a polity. Kaos GL raises its claim for the constitutional recognition of conscientious objection. ${ }^{14}$ It demands the state to consider GBT individuals who do not want to do their military service under the rubric of conscientious objection. This initiative acknowledges both the ability of GBT individuals to do their military service if they wish, and the right of GBT individuals to claim their own differences if and when they do not wish to do their military service.

LGBT organizations' contribution to the equality/difference debate is further tied to the conception of radical democracy. Queer politics, which recognizes identity in nonessentialist and intersectional terms, brought about the recognition of various subjectivities within the community (Seidman 2001). The horizontal and democratic decision-making process in initiatives, the positive discrimination for women/transgenders within the LGBT meetings, and the collaboration of different LGBT organizations within democratic platforms, points to the recognition of different subject positions within the community. Recognition of intersectionality also resulted in the expansion of concerns, as manifested in SPOD's data collection of socio-economic status of LGBT people living in Turkey and social policies.

Muslim women's associations have defended the right to education and work of women with headscarves with an "equality through difference " platform. AKDER defines one of its missions as "working towards enabling individuals to live, work and receive education without compromising their beliefs, " where such a compromise is defined permanently or temporarily by taking off their headscarf. ${ }^{15}$ In other words, equal access should not require relinquishing one's difference. Instead, there is a demand to exist in the public space with a freely formed identity. ${ }^{16}$

14 Maddeye Ek: LGBT realitesi tanınsın! http://www.kaosgl.com/sayfa.php?id=10216, available on June 12, 2012.

15 AK-DER mission statement: http://www.ak-der.org/misyon.gbt., available on June 12, 2012.

16 For Özipek, see: http://www.ak-der.org/insan-haklari-ve-ihlaller-ekseninde-bir-ornek-turkiyede-basortusu-yasagi-sorunu.gbt and Benli: http://www.ak-der.org/hukuki-boyutlariylaturkiyede-basortulu-kadinlara-yonelik-ayrimcilik_bolum1-.gbt, available on June 12, 2012. 
What is at stake in the recognition of difference is »the ability of the individual to determine his/her identity ... This is not limited to the right to have an identity in private spaces but includes the freedom to choose how the person wants to be perceived by the state and present herself to the others. ${ }^{17}$ The Platform has identified both the conservative and the secular segments of society as publics that covered women encounter through their difference. ${ }^{18}$ As articulated in their vision statement, the problems encountered by these women arise out of both the religious interpretations that strengthen the traditional role of women and the modern prejudices against religious women. In advocating for the equality of these women, AK-DER has focused on the equal right of citizens to become public servants, except in the cases of crimes punishable by law. For them, neutrality is not to be sought in the attire but instead in concrete decisions they make. Both AKDER and the Platform objected to the limited joint proposal by AKP and MHP for the relaxation of the headscarf ban ${ }^{19}$ by arguing that difference is not to be recognized conditionally, which makes future reinterpretation and marginalization a possibility. ${ }^{20}$

In arguing for equality through difference, both groups rely on a nonessentialist, or in Lister's terms, a weaker notion of difference. This understanding of difference is inseparable from their unique position as "women " and "Muslims, " enabling different alliances. The Platform's founding member, Özden Gültekin, points out how the movement grew out of Muslim women's discontent with the traditional roles expected of them, and their desire to not only establish families, but also to work. ${ }^{21}$ Platform members initially felt unwelcomed by secular feminists as they began to participate in women's human rights meetings. This difficult position has in time transformed into a wide array of alliances, with feminist groups on issues of women's rights, antimilitarist groups within the scope of the Kurdish question, and other Muslim associations around issues such as the IsraeliPalestinian conflict. AK-DER has been vocally critical of the disregard for Muslim women's perspective in the laws targeting the problems they face. Much like the

17 See http://www.ak-der.org/hukuki-boyutlariyla-turkiyede-basortulu-kadinlara-yonelik-ayrimcilik-bolum1-.gbt., available on June 10, 2012.

18 For Mission Statement, see: http://www.baskentkadin.org/tr/?cat=6, available on June 10, 2012.

19 For AK-DER's proposals, pronouncements and activities, see: http://www.ak-der.org/egitimhakkinin-engellenmesi-ile-mucadele-yollari.gbt, and http://www.ak-der.org/faaliyetlerimiz. gbt., available on June 10, 2012.

20 For AK-DER's criticism, see the preceding endnote. For Başkent Women's Platform's criticism, see: http://www.yeniasya.com.tr/haber_detay2.asp?id=12238, available on June 12, 2012.

21 http://www.baskentkadin.org/tr/?p=188\#more-188, available on June 10, 2012. 
Platform's Hidayet Şefkatli Tuksal, ${ }^{22}$ who criticized the AKP for instrumentalizing Muslim women, AK-DER's Secretary General, Neslihan Akbulut Arıkan, has recognized that most of the reactions to their campaign on the inclusion of headscarf wearing candidates in parliamentary elections came from the pious segments. ${ }^{23}$

\section{A New Public and Counterpublics}

The separation of the public and private is integral to the definition of the political. In Turkey, the challenge to existing public space began in the late 1980 os with the claims of Alevis, Kurds and religious groups (Bozarslan 1997). They created a space for the later emergence of ideational claims of the other movements (i.e., feminists and LGBTs in the 1990s).

LGBT organizations subscribed to the feminist perspective that the "personal is political. "They politicized everyday life experiences to challenge the implicit heteronormative contract leading to a particular public. The demand for state policies to prevent hate crimes, such as awareness-raising measures, protection by lawyers and the police force, is one example of this struggle. The dialogues between LGBT organizations and several ministers, ${ }^{24}$ and the resulting parliamentary motion $s^{25}$ for the investigation of governmental activities towards the prevention of hate crimes are some of the outcomes. The critique includes legal obstacles to LGBT couples forming families. Nonrecognition of nonheterosexual relations by social policies, based on family composition, is diagnosed as the main obstacle to LGBTs. Although there is still not a collective demand for gay marriage, one female-to-male transgender woman with a pink identity card and a self-identified gay man with a blue identity card, both KAOS GL activists, challenged the heteronormative mentality of state by attempting to legally marry.

In 2009, the heteronormative character of the state was strenuously contested after the former state minister for women's affairs Selma Aliye Kavaf's statement that, "homosexuality is a biological disorder, a disease [...] it is something that

22 http://t24.com.tr/haber/hidayet-sefkatli-tuksal-akp-de-basortulu-kadinlari-itibarsizlastirdi/188261, available on June 11, 2012.

23 http://www.ak-der.org/12-nisan-2011.gbt., available on June 11, 2012.

24 Nursuna Memecan (AKP), Sebahat Tuncel (BDP), Sırrı Süreyya Önder (BDP), and Mehmet Sevigen (CHP) are some ministers that the organizations contacted; http://bianet.org/bianet/toplumsal-cinsiyet/115501-tuncel-meclis-lgbtt-orgutlerini-de-muhatap-almali, available on June 12, 2012.

25 See Sebahat Tuncel's parliamentary motion; http://bianet.org/bianet/bianet/121143-bdplituncel-hukumete-nefret-suclarina-karsi-ne-yaptigini-sordu, available on June 12, 2012. 
should be treated. $\aleph^{26}$ In response, LGBT organizations raised their concerns about the representation of their interests at the state level. They insisted that ministers should be neutral towards different sexual identities. Lambdaistanbul filed a court case against Kavaf, advocating that such actions of state officials violate the impartiality of the state and increases the possibility of hate crimes towards already »victimized « groups. The statement »transgender killings are political, « problematizes the state's reluctance to consider it as a political issue. Gay individuals, such as Baki Koşar, and Ahmet Yıldız, who were murdered, as well as several other killings targeting the transgenders, have been brought up in anti-hate crime campaigns. ${ }^{27}$ Ahmet Yuldiz's case is considered the first gay honor killing. Lambdaistanbul and Kaos GL counter the separation of public and private, which legitimizes honor killings. Acknowledging that these problems can be ameliorated through the politicization of LGBT individuals, SPOD carried out courses on various political issues. ${ }^{28}$ In a radio broadcast, a SPOD representative argued that these courses aimed at encouraging future representatives of LGBTs in the parliament. $^{29}$

Muslim women's associations establish the private-public connection through a focus on domestic violence. Both AK-DER and the Platform, share a conservative emphasis on the sacredness of the family. However, they depart from a conservative interpretation that prioritizes the family in all instances by arguing that domestic violence is unacceptable, and is a public matter. Both have put forth amendment proposals to Turkey's domestic violence law. In its proposal, AK-DER argues that at the moment of violence, the family has already dissolved, and it is the responsibility of the state to protect the vulnerable individuals, namely the women and children. ${ }^{30}$ They argue that mechanisms preventing domestic violence do not increase divorce rates. Rather, these mechanisms intervene in moments when the marriage has already departed from its normal course. Arising out of women's lived experiences, the proposal demands the inclusion of unmarried couples who cohabit like a family., ${ }^{31}$ It further argues for the prevention of the violent actor from going not only to the home and workplace, but to all places that

26 http://www.cnnturk.com/2010/turkiye/o3/o7/bakan.kavaf.escinsellik.bir.hastalik/566620.o/ index.html, available on June 12, 2012.

27 http://bianet.org/bianet/lgbtt/138402-homofobiye-karsi-mucadelenin-sembolleri

28 For the activities of SPOD, see http://www.spod.org.tr/, available on June 12, 2012.

29 The program can be accessed on http://www.spod.org.tr/turkce/spod-acik-radyodaydi/, available on June 12, 2012.

30 See http://www.ak-der.org/ailenin-korunmasina-dair-kanun-tasarisi-hakkindaki-gorusler2006.gbt, available on June 11, 2012.

31 This demand for inclusion is likely to be rooted in the existence of couples who are united by a religious marriage. Yet, it is also rooted in the lived experiences of women. 
the woman frequents, such as the children's school, as well as the prevention of the police from turning away women victims of violence by saying "it is a private matter."

The two associations point out that patriarchal gender norms imbue pervade both the public and private. They result in either the formulation of discriminatory laws or the discriminatory implementation of laws. The Platform has pointed out that in both secular and Islamist regimes, traditional gender norms negatively affect laws on women's inheritance. ${ }^{32}$ The AK-DER underlines that because since until recently properties could be owned under men's name only, the nonrecognition of this inequality in divorce laws resulted in ignoring women's contribution to the acquisition of mutual property, and making divorce a difficult decision for them. ${ }^{33}$ Similarly, the AK-DER has proposed that family courts automatically grant the payment of a basic level of alimony to the women, starting with the postviolence separation of the spouses.

Lastly, Muslim women contest the particular conceptualization of "public space (kamusal alan) as "state space. «In other words, in the aftermath of the 28 February coup, the narrow public space of the Turkish republic received a new gradation that further narrowed by exclusion through its identification as a state space, where women with the headscarf could not be employed as public officials, serve in courts as lawyers, or receive higher education. In contesting this exclusion, the AK-DER has argued that since all nonprivate space is de facto public, and since a group of citizens cannot be confined to their homes, the solution lies in opening up the public space in its entirety to women with headscarves. The public space is also challenged by the formation of counterpublics. The associations themselves have been important in this respect, ${ }^{34}$ providing a separate space for Muslim women, who were included in Islamist mobilizations mainly through "social work, « to discuss and place on the public agenda their experiences of discrimination. The AK-DER organized counter-public days, with other civil society organizations, thereby defining counter-public as a space of communication. ${ }^{35}$

As demonstrated above, both groups use juridico-political instruments to push for a more inclusive public space, while at the same time posing more fundamental questions about the masculine essence of public. Yet, Muslim Women's Organizations emphasize the sacred character of the family while, conversely, this sacredness becomes an impediment to the LGBTs. Thus, although they have en-

32 For meeting notes, see http://www.baskentkadin.org/tr/?p=61, available on June 12, 2012.

33 See http://www.ak-der.org/ailenin-korunmasina-dair-kanun-tasarisi-hakkindaki-gorusler2006.gbt, available on June 10, 2012.

34 For notes from a field visit, see http://www.baskentkadin.org/tr/? $\mathrm{p}=61$, available on June 11, 2012.

35 http://www.ak-der.org/1-eylul-2007.gbt, available on June 11, 2012. 
gaged in dialogues on specific issues, for a more democratic plural polity to be established, there is a need to move beyond the constructed moral hierarchy between the sacred and the nonsacred.

\section{Solidification of Claims: Proposals for a New Constitution}

Muslim Women's ${ }^{36}$ and LGBT $^{37}$ organizations have actively participated in the new constitutional process which was initiated in the aftermath of the 2010 elections. Both affirm the importance of the inclusive, transparent, democratic, and accountable constitution making process. The demand is for inclusive citizenship that extends to other minorities' rights, such as Kurds, disabled people, Alevis, and non-Muslims. Muslim women's groups extend this also to the elderly and the sickly, but not to sexual minorities. The Platform explicitly argues that citizenship should be removed from all ethnic, religious and cultural concepts, without disregarding difference. This neutrality demand also comes out of the surveys that SPOD conducted with LGBTs, who stress the necessity of an ideology- and ethnicity-free constitution. The state is defined as the guarantor of the individual rights and freedoms, not granting, but instead ensuring, the practice of rights by citizens. Some of the concrete proposals are the clear regulation of hate crime by law. The Platform argues that the headscarf ban should be considered a hate crime. LGBTs are additionally cognizant of the ways in which vague constitutional terminology - public morality, propriety and public peace - have been used against LGBTs.

For the secular nature of the state to be established, Muslim Women's Organizations stress that the ability to become a public official should not be conditioned on one's attire. The demand for the state to be neutral vis-à-vis religious and nonreligious attire moves Turkey closer to secularism as it is practiced in many other European countries. Similarly, LGBT organizations demand that the state consider secularism at the universal level - although what " universal « means is not clearly defined. Both groups also voice their desire for a welfare state; however, Muslim women's organizations argue that welfare policies should focus on creating gender equality through not only the empowerment of women, but also on the protection of family as a unit. For their part, LGBT organizations argue that social policies should take as their basis the individual rather than the family. It is only LGBT or-

36 For the AK-DER's proposal, see: http://www.ak-der.org/akderin-yeni-ve-sivil-bir-anayasaicin-onerileri.gbt. For Başkent Women's Platform, see http://anayasaizleme.com/yenianayasaonerileri/, available on June 11, 2012.

37 For the SPOD's, Kaos GL's and Pembe Hayat's proposals see: http://www.spod.org.tr/turkce/ wp-content/uploads/2012/o6/SPoD-Anayasa-Raporu.pdf, available on June 12, 2012. 
ganizations that argue for positive discrimination, such as quotas for women. The Platform, on the other hand, proposes the application of a »Belonging Scale « to monitor the employment policies of the public and private sector vis-à-vis gender, attires, ethnicity, cultural and philosophical identification. Both emphasize the extra-legal restriction of rights as an impediment to the participation of marginalized groups in public life. Muslim women's organizations argue that fundamental rights can be subject to restriction only in line with the constitution and through laws. Kaos GL further emphasizes the injustice of punishment without a legal basis.

Finally, both situate their demands within the framework of international laws and norms, including human rights. The SPOD and Pembe Hayat argue that the state should consider Yogyakarta Principles: the implication of international human rights law in relation to sexual orientation and gender identity; the Amsterdam Treaty of 1999; and the European Council Directive 2000/78. Başkent Women's Platform, AK-DER, SPOD, Pembe Hayat and Kaos GL also refer to the Convention on the Elimination of Discrimination against Women, to which Turkey is a signatory.

\section{Conclusion}

We argue that the transcendence of binaries by these groups creates the possibility of a radical democratic conceptualization of the polity. These groups use liberal notions of self-protection, self-realization and self-esteem to challenge the republican notion of Turkish citizenship without losing sight of public-spiritedness. The advocacy of equality within plurality results from an acknowledgement of intersectional subject positions, and enables an ethico-political stance. The first glimpses of this stance are observed in the mutual participation in campaigns targeting violence against women, reform efforts to the penal code, and a curb on military spending. These groups blur the boundaries between the public and the private, and constantly redefine the political from different sides, yet through similar mentalities which indicate their ability to transform the polity to an open-ended process. The open-ended reformulation of the polity, the equivalence of democratic actors through a common ethico-political identification, and an awareness of public-spiritedness with continued respect for individual rights, bring us to a radical democratic possibility in which plurality is recognized in social, political and economic spheres.

Nonetheless, we should be cautious about lingering difficulties towards their dialogical engagement. We have pointed to the Muslim women's sacralizing of the family, and the hierarchy this creates as an obstacle to dialogical engagement 
with LGBTs as equals. Further, while beyond the scope of discussion in this paper, there have also been instances of difficult engagement in the recent past (i.e. LGBT organizations' objections to Hilal Kaplan's presence in a conference on hate crimes), arising out of unfavourable newspaper articles she had written on homosexuality. Thus, we recognize the existence of tensions among these groups. These tensions are real, but not definite and inevitable impediments to a common "grammar of conduct. "Indeed, there have been instances where both groups manage to support one another despite the pressure of conservative groups. When the signature of Kaos GL in AK-DER’s campaign, «28 Şubat 1000 Yll Süremez, Kaldırın Başörtüsü Yasaklarını, « disturbed certain conservative groups, AK-DER and Başkent Women's Platfrom activists called Kaos GL activists personally and explained their difficult situation, while also making their excuses. The groups managed to find common ground. Finally, Kaos GL took back its institutional signature for a favorable outcome in the campaign. Yet Muslim women activists proposed that LGBT activists sign the petition individually with their institutional affiliation attached to their names. The process ended with a common acknowledgement that "both groups need to acquire more experiences together in their struggle against a world where these conservative groups could bear both groups' demands for living together. ${ }^{38}$

\section{References}

AK-DER. 2008. Başörtüsü neden yasak? Çok dillendirilen yasak gerekçelerinin analizi. Available online at: http://www.ak-der.org/basortusu-neden-yasak--2008.gbt. June $10,2012$.

AK-DER. 2008. Örtülemeyen sorun başörtüsü. Available online at: http://www.ak-der.org/ ortulemeyen-sorun-basortusu---kitap---onsoz.gbt. June 10, 2012.

Bozarslan Hamit. 1996-1997. Le chaos après le déluge : notes sur la crise turque des annèes 70. Cultures \& Conflits. Available online at: http://conflits.revues.org/index501.html. June 10, 2012.

Dworkin, Ronald. Taking rights seriously, London: Duckworth, 1977.

Fraser, Nancy. 1992. » Rethinking the public sphere: a contribution to the critique of actually existing democracy.«. In Habermas and the Public Sphere, edited by Craig Calhoun. 109-142. Cambridge: MIT Press.

Kadıŏlu, Ayşe. 2005. »Can we envision Turkish citizenship as non-membership? « In Citizenship in a Global World: European questions and Turkish experience, edited by Fuat Keyman and Ahmet İçduygu. 105-124. London: Routledge.

38 For a detailed account of AK-DER, Başkent Women's Organization and Kaos GL activists, see http://www.kaosgl.com/sayfa.php?id=4413, available on February 27, 2012. 
Keyman, Fuat, İçduygu, Ahmet. 2003. »Globalization, civil society and citizenship in Turkey: actors, boundaries and discourses. "Citizenship Studies 7,2: 219-234

Lister, Ruth. 2003. Citizenship: feminist perspectives. New York: Palgrave McMillan, 2003.

Longo, Patrizia. 2001. »Revisiting the equality/difference debate: redefining citizenship for the new millennium. « Citizenship Studies 5,3: 269-283.

Mouffe, Chantal. 1992. »Democratic citizenship and political community. «In Dimensions of Radical Democracy: Pluralism, citizenship and community, edited by Chantal Mouffe. 70-82. London: Routledge.

Mouffe, Chantal. 1995. »Feminism, citizenship and radical democratic politics. «In Social postmodernism: Beyond identity politics, edited by Linda Nicholson and Steven Seidman. 369-384. Cambridge: Cambridge University Press.

Pateman, Carole. 1988. The sexual contract, California: Stanford University Press, 1988.

Pocock, John. 1995. »The ideal of citizenship since classical times. «In Theorizing Citizenship, edited by Ronald Beiner. 29-53. Albany: State University of New York Press.

Rawls, John. A theory of justice, Oxford: Oxford University Press, 1972.

Rousseau, Jean J. On the social contract: with Geneva manuscript and political economy, New York: St. Martin's Press, 1978.

Seidman, Steven. 2001 "From identity to queer politics: shifts in normative heterosexuality and the meaning of citizenship. « Citizenship Studies 5,3: 321-328.

Soysal, N. Yasemin. 1997. „Changing parameters of citizenship and claims-making: organized Islam in European public spheres. « Theory and Society 26,4: 509-527.

Sosyal Politikalar Derneği. 2012. Activity Reports. Available online at: http://www.spod.org. tr. June 10, 2012.

Open Access. This chapter is distributed under the terms of the Creative Commons Attribution Noncommercial License, which permits any noncommercial use, distribution, and reproduction in any medium, provided the original author(s) and source are credited. 